\title{
Lethal outcome of granulomatous acanthamoebic encephalitis in a man who was human immunodeficiency virus- positive: a case report
}

\author{
Stefanie Geith ${ }^{1 *}$, Julia Walochnik ${ }^{2}$, Franz Prantl ${ }^{3}$, Stefan Sack and Florian Eyer $^{1}$
}

\begin{abstract}
Background: Acanthamoeba species can cause disseminating infections in immunocompromised individuals.

Case presentation: Here, we report a case of granulomatous acanthamoebic encephalitis with a lethal outcome in a 54-year-old German man who was human immunodeficiency virus-positive. The diagnosis was based on symptoms of progressive neurological deficits, including sensorimotor paralysis of his right leg and deteriorating alertness. Due to the rapid course and rather late diagnosis of the infection, effective treatment could not be applied and he died 12 days after hospital admission.

Conclusions: To the best of our knowledge, this is the second case of granulomatous acanthamoebic encephalitis reported within Germany. Our case highlights the importance of early diagnosis of granulomatous acanthamoebic encephalitis to prevent fatal outcome.
\end{abstract}

Keywords: Acanthamoeba species, GAE, HIV, Miltefosine treatment

\section{Background}

Acanthamoeba species are free-living amoeboid single-cell organisms that naturally occur in water and soil, but can also be found in human-made habitats all over the world [1-5]. Acanthamoeba species are known as causal agents of disseminating infections in immunocompromised individuals (for example, human immunodeficiency virus (HIV) positive, immunosuppressive therapy), including granulomatous acanthamoebic encephalitis (GAE) [6-8]. GAE is a rare but mostly fatal disease [6, 9]. Furthermore, Acanthamoeba species can cause so-called Acanthamoeba keratitis; Acanthamoeba keratitis mainly occurs in contact lens wearers and increasing casualties have been reported in the past decades $[10,11]$.

\footnotetext{
* Correspondence: Stefanie.Geith@mri.tum.de

${ }^{1}$ Division of Clinical Toxicology \& Poison Control Centre Munich, Department of Internal Medicine II, TUM School of Medicine, Technical University of Munich, Ismaninger Str. 22, 81675 Munich, Germany

Full list of author information is available at the end of the article
}

\section{Case presentation}

In December 2010, a 54-year-old German man presented to our hospital with suspected cerebral toxoplasmosis. HIV infection had been diagnosed in 1995. He had received a triple-combination highly active antiretroviral therapy (HAART) of lopinavir, lamivudine, and tenofovir, which was stopped in 2009 due to intolerable side effects (diarrhea, nausea).

Over a period of 5 days, progressive neurological deficits including sensorimotor paresis of his right leg and deterioration of alertness occurred.

On clinical and neurological examination, he showed high-grade flaccid paralysis of his right lower limb with preserved muscle proprioceptive reflexes and positive Babinski sign.

Magnetic resonance imaging (MRI) on day 1 revealed a periventricular hyperintense lesion with perifocal edema in the left parieto-occipital region which continued to progress as shown in imaging on day 6 (Fig. 1).

Blood laboratory values on day 1 revealed leukopenia $(3.4 / \mathrm{nL})$ and thrombocytopenia $(101 / \mathrm{nL})$. 


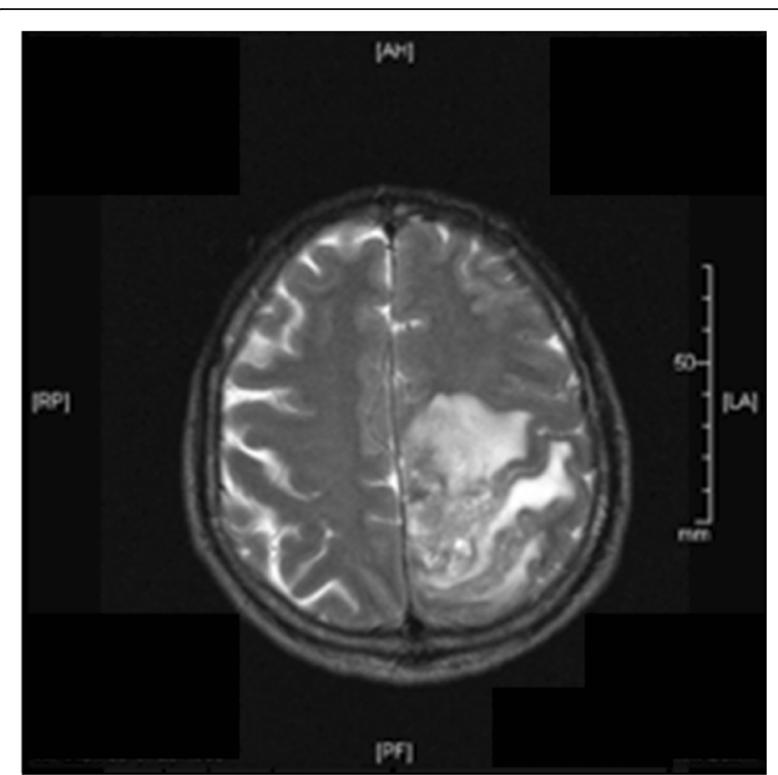

Fig. 1 Magnetic resonance imaging on day 6 with pronounced perifocal edema in the left parieto-occipital region

No fungi, viruses (except HIV-1), or bacteria were detected in blood and cerebrospinal fluid cultures nor in serologic tests and polymerase chain reaction (PCR; Table 1). Prophylactic antibiotic treatment (antifungal, antiviral, antibacterial, and antiprotozoal) was administered as listed in Table 2. Immunocytology of
Table 2 Initial antibiotic treatment

\begin{tabular}{lll}
\hline Medication & Daily dose & $\begin{array}{l}\text { Route of } \\
\text { administration }\end{array}$ \\
\hline Pyrimethamine & $37.5 \mathrm{mg}$ & Orally \\
Fluconazole & $2 \times 100 \mathrm{mg}$ & Intravenously \\
Clindamycin & $1800 \mathrm{mg}$ & Intravenously \\
Ceftriaxone & $2 \mathrm{~g}$ & Intravenously \\
Aciclovir & $3 \times 750 \mathrm{mg}$ & Intravenously \\
Meropenem & $3 \times 1 \mathrm{~g}$ & Intravenously \\
\hline
\end{tabular}

cerebrospinal fluid on day 5 showed a reduced absolute lymphocyte count $(640 / \mu \mathrm{L})$, reduced T-helper cells $(\mathrm{CD} 3,365 / \mu \mathrm{L})$, and a pathologic $\mathrm{CD} 4 / \mathrm{CD} 8$ ratio.

Due to pathologic MRI findings, a stereotactic biopsy was performed on day 9. Histopathological results obtained on day 12 showed extensive tissue necrosis with mixed inflammatory infiltrates. Cysts of Acanthamoeba species were detected in periodic acid-Schiff (PAS) and Grocott stainings of brain specimens. Mononuclear trophozoites could be identified in hematoxylin and eosin (HE) and PAS stainings (Fig. 2). Furthermore, additional immunohistochemical staining was performed using an antibody specific to Acanthamoeba species (from rabbits immunized with Acanthamoeba genotype 4; Fig. 3).

Electroencephalography (EEG) on day 6 showed a lesion located in his left frontotemporal region with epileptic patterns in the left parietal lobe. He developed relapsing

Table 1 Results of diagnostics in cerebrospinal fluid, blood, serum, and bronchoalveolar lavage

\begin{tabular}{|c|c|c|}
\hline Disease/Pathogen & Test & Result \\
\hline Human immunodeficiency virus & $\begin{array}{l}\text { Liquor, PCR } \\
\text { Serum, PCR }\end{array}$ & $\begin{array}{l}\text { Positive }(670,000 \text { copies } / \mathrm{mL}) \\
\text { Positive }(2,200,000 \text { copies } / \mathrm{mL})\end{array}$ \\
\hline Toxoplasmosis & Immunohistochemistry & Negative \\
\hline Measles & $\begin{array}{l}\text { Liquor, } \\
\text { Serum, IgG } \\
\text { Serum, IgM }\end{array}$ & $\begin{array}{l}\text { Negative } \\
\text { Positive (IgG } 1900 \text { U/L) } \\
\text { Negative }\end{array}$ \\
\hline Borrelia & Liquor, IgG & Negative \\
\hline Syphilis & Liquor, TPPA & Negative \\
\hline FSME & $\begin{array}{l}\text { Liquor, IgG } \\
\text { Serum, IgG/lgM }\end{array}$ & $\begin{array}{l}\text { Negative } \\
\text { Both negative }\end{array}$ \\
\hline Cryptococcus & Liquor, antigen screen & Negative \\
\hline HSV $1 / 2$ & $\begin{array}{l}\text { Liquor, DNA } \\
\text { BAL, DNA }\end{array}$ & $\begin{array}{l}\text { Negative } \\
\text { Positive }\end{array}$ \\
\hline VZV (herpes zoster) & Liquor, PCR & Negative \\
\hline CMV & $\begin{array}{l}\text { Liquor, PCR } \\
\text { BAL, PCR }\end{array}$ & $\begin{array}{l}\text { Negative } \\
\text { Negative }\end{array}$ \\
\hline EBV & Liquor, PCR & Negative \\
\hline JCV (human polyomavirus) & $\begin{array}{l}\text { Liquor, PCR } \\
\text { BAL, PCR }\end{array}$ & $\begin{array}{l}\text { Negative } \\
\text { Negative }\end{array}$ \\
\hline $\mathrm{HCV}$ & Serum, PCR & Negative \\
\hline Enterococcus & BAL & Positive \\
\hline
\end{tabular}

BAL bronchoalveolar lavage, CMV cytomegalovirus, EBV Epstein-Barr virus, FSME tick-borne encephalitis, HCV hepatitis C virus, HSV herpes simplex virus, JCV John Cunningham virus, $P C R$ polymerase chain reaction, TPPA Treponema pallidum particle agglutination assay, VZV varicella zoster virus 

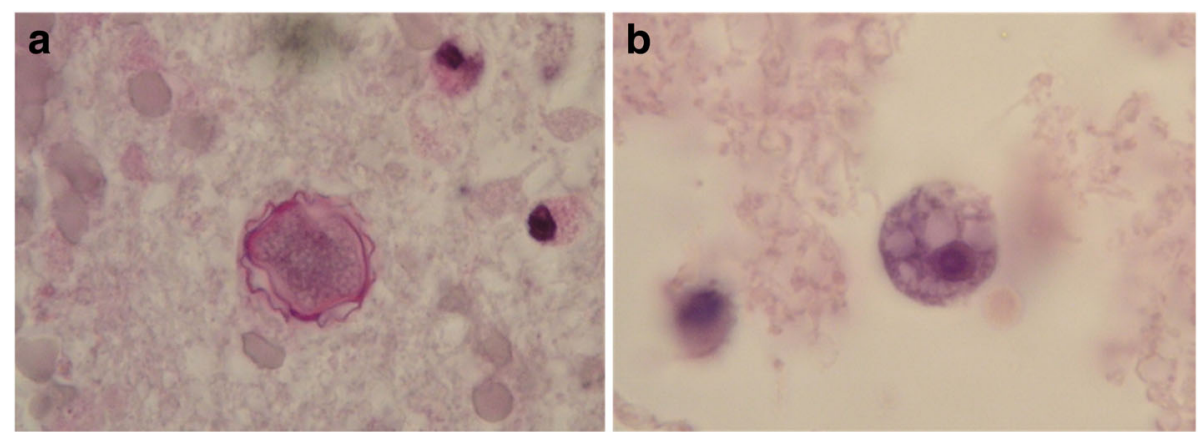

Fig. 2 Acanthamoeba species. a Cyst with periodic acid-Schiff staining and $\mathbf{b}$ rounded trophozoite with hematoxylin and eosin staining $(\times 1000)$

tonic-clonic seizures which normalized by day 8 following anticonvulsive therapy with valproic acid, methohexital, levetiracetam, and clonazepam.

MRI on day 11 revealed a new and massive ubiquitous subarachnoid hemorrhage, a beginning compression, a generalized cerebral swelling, and, an expanding left parietal periventricular lesion.

Due to the unfavorable prognosis, we, in agreement with his relatives, took no further intensive care measures. He died on day 12 after hospital admission.

Since histopathology did not reveal GAE before day 12, a specific treatment against GAE (for example, miltefosine-based combination therapy) had not been initiated.

\section{Discussion and conclusions}

Infections with Acanthamoeba species are rare; hence, clinicians, pathologists, and clinical microbiologists are generally unfamiliar with these diseases. The vast majority of cases of GAE reported in the literature have been diagnosed postmortem [12, 13]. To the best of our knowledge, this is the second case of GAE reported within Germany.

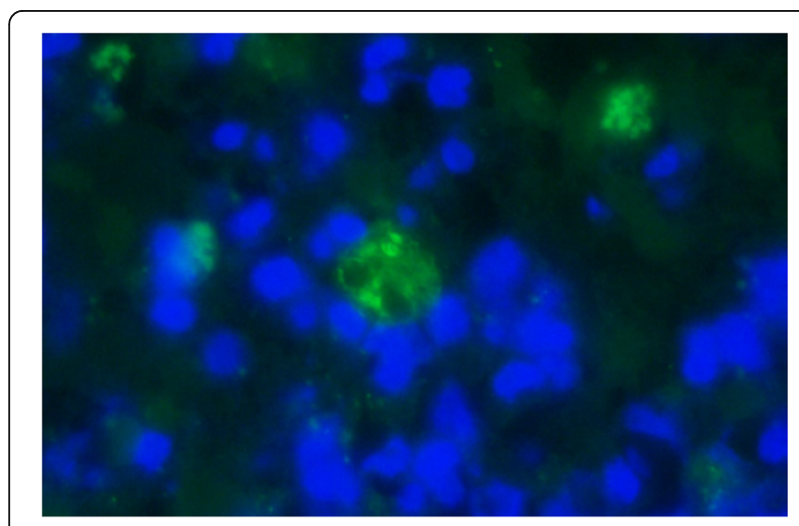

Fig. 3 Immunostained Acanthamoeba trophozoite with characteristic nucleus and prominent contractile vacuole (Multichannel $\times 400$ )
The current case emphasizes the importance of early diagnosis of GAE. Microscopy of centrifuged fresh cerebrospinal fluid is recommended to diagnose Acanthamoeba trophozoites, yet these may be misdiagnosed as macrophages. Histological staining enables a clear differentiation of trophozoites from other cells [13]. Today, PCR is the method of choice for rapid, specific, and sensitive detection of Acanthamoeba species in clinical samples and also allows genotype identification [14] as well as diagnosis from formaldehyde-fixed samples $[15,16]$. Early diagnosis and specific treatment is only possible if an infection with Acanthamoeba species is suspected early [13].

Today, there is no standard regimen for the treatment of GAE, but several successfully treated cases have been reported. For example: a patient with acquired immunodeficiency syndrome (AIDS) was treated with a combination of fluconazole and sulfadiazine [17]; two immunocompetent children received trimethoprim-sulfamethoxazole, rifampicin, and ketoconazole [18]; another immunocompetent woman was treated with fluconazole, rifampicin, and metronidazole [13]; a young immunocompromised man with underlying tuberculosis was treated with miltefosine, amikacin, and tuberculostatic drugs [8]; and, another young immunocompetent man was treated with rifampicin, moxifloxacin, and fluconazole [19]. The Centers for Disease Control and Prevention (CDC) recommends administration of miltefosine based on 26 reported cases in which a miltefosine-including regimen seemed to offer a survival advantage [20].

Our patient was prophylactically treated with antibiotics, covering antifungal, antiviral, antibacterial, and antiprotozoal activity. $\mathrm{He}$ did not receive a miltefosine-based combination therapy. As pointed out earlier, most reported cases of GAE have been diagnosed postmortem [12] and all successfully treated cases were detected early and mainly by chance. Therefore, both awareness and an early and specific diagnosis followed by an immediate start of a miltefosine-based treatment seem of crucial 
importance for the successful treatment of GAE. Acanthamoeba species should be considered in patients with unclear encephalitis, particularly in immunocompromised patients.

\section{Abbreviations}

AIDS : Acquired immunodeficiency syndrome; CDC: Centers for Disease Control and Prevention; EEG: Electroencephalography; GAE: Granulomatous amoebic encephalitis; HAART: Highly active antiretroviral therapy; HE: Hematoxylin and eosin; MRI: Magnetic resonance imaging; PAS: Periodic acid-Schiff; PCR: Polymerase chain reaction

\section{Availability of data and materials}

All data (pictures) generated or analyzed during this study are included in this published article.

\section{Authors' contributions}

SG treated the patient, collected the data, and wrote the manuscript. JW performed histological staining and took Multichannel pictures. FP provided PAS-stained and $\mathrm{HE}$-stained pictures. SS treated the patient and contributed with analysis and interpretation of data. FE made substantial contributions to the interpretation of data and manuscript review. All authors read and approved the final manuscript.

\section{Ethics approval and consent to participate}

No ethics approval, but patient's relatives consented (see below).

\section{Consent for publication}

Written informed consent was obtained from the patient's next of kin for publication of this case report and any accompanying images. A copy of the written consent is available for review by the Editor-in-Chief of this journal.

\section{Competing interests}

The authors declare that they have no competing interests.

\section{Publisher's Note}

Springer Nature remains neutral with regard to jurisdictional claims in published maps and institutional affiliations.

\section{Author details}

'Division of Clinical Toxicology \& Poison Control Centre Munich, Department of Internal Medicine II, TUM School of Medicine, Technical University of Munich, Ismaninger Str. 22, 81675 Munich, Germany. ${ }^{2}$ Medical University of Vienna, Center for Pathophysiology, Infectiology and Immunology, Institute of Specific Prophylaxis and Tropical Medicine, Kinderspitalgasse 15, 1090 Vienna, Austria. Institute of Pathology, Academic Clinic Munich-Schwabing, Kölner Platz 1, 80804 Munich, Germany. ${ }^{4}$ Department of Cardiology, Pneumology and Internal Intensive Medicine, Academic Clinic Munich-Schwabing, Kölner Platz 1, 80804 Munich, Germany.

Received: 4 December 2017 Accepted: 3 June 2018

Published online: 12 July 2018

\section{References}

1. Staggemeier R, Arantes T, Caumo KS, Rott MB, Spilki FR. Detection and quantification of human adenovirus genomes in Acanthamoeba isolated from swimming pools. An Acad Bras Cienc. 2016;88(Suppl 1):635-41.

2. Al-Herrawy A, Bahgat M, Mohammed AE, Ashour A, Hikal W. Acanthamoeba species in swimming pools of Cairo, Egypt. Iran J Parasitol. 2014;9:194-201.

3. Pernin P, Riany A. Study on the presence of "free-living" amoebae in the swimming-pools of Lyon (author's transl). Ann Parasitol Hum Comp. 1978; 53:333-44.

4. Donati M, Cremonini E, Di Francesco A, Dallolio L, Biondi R, Muthusamy R, Leoni E. Prevalence of Simkania negevensis in chlorinated water from spa swimming pools and domestic supplies. J Appl Microbiol. 2015;1 18:1076-82.

5. Gianinazzi C, Schild M, Wuthrich F, Muller N, Schurch N, Gottstein B. Potentially human pathogenic Acanthamoeba isolated from a heated indoor swimming pool in Switzerland. Exp Parasitol. 2009;121:180-6.

6. Schuster FL, Visvesvara GS. Opportunistic amoebae: challenges in prophylaxis and treatment. Drug Resist Updat. 2004;7:41-51.
7. Visvesvara GS. Amebic meningoencephalitides and keratitis: challenges in diagnosis and treatment. Curr Opin Infect Dis. 2010;23:590-4.

8. Aichelburg AC, Walochnik J, Assadian O, Prosch H, Steuer A, Perneczky G, Visvesvara GS, Aspöck H, Vetter N. Successful treatment of disseminated Acanthamoeba sp. infection with Miltefosine. Emerg Infect Dis. 2008;14: 1743-6.

9. Meersseman W, Lagrou K, Sciot R, de Jonckheere J, Haberler C, Walochnik J, Peetermans WE, van Wijngaerden E. Rapidly fatal Acanthamoeba encephalitis and treatment of Cryoglobulinemia. Emerg Infect Dis. 2007;13: 469-71.

10. Marciano-Cabral F, Cabral G. Acanthamoeba spp. as agents of disease in humans. Clin Microbiol Rev. 2003;16:273-307.

11. Lorenzo-Morales J, Khan NA, Walochnik J. An update on Acanthamoeba keratitis: diagnosis, pathogenesis and treatment. Parasite. 2015;22:10.

12. Bloch $\mathrm{KC}$, Schuster FL. Inability to make a premortem diagnosis of Acanthamoeba species infection in a patient with fatal granulomatous amebic encephalitis. J Clin Microbiol. 2005;43:3003-6.

13. Petry F, Torzewski M, Bohl J, Wilhelm-Schwenkmezger T, Scheid P, Walochnik J, Michel R, Zöller L, Werhahn KJ, Bhakdi S, Lackner KJ. Early diagnosis of Acanthamoeba infection during routine cytological examination of cerebrospinal fluid. J Clin Microbiol. 2006;44:1903-4.

14. Schroeder JM, Booton GC, Hay J, Niszl IA, Seal DV, Markus MB, Fuerst PA, Byers TJ. Use of subgenic $18 \mathrm{~S}$ ribosomal DNA PCR and sequencing for genus and genotype identification of Acanthamoebae from humans with keratitis and from sewage sludge. J Clin Microbiol. 2001;39:1903-11.

15. Walochnik J, Scheikl U, Haller-Schober E-M. Twenty years of Acanthamoeba diagnostics in Austria. J Eukaryot Microbiol. 2015;62:3-11.

16. Walochnik J, Obwaller A, Haller-Schober EM, Aspock H. Anti-Acanthamoeba $\lg G$, IgM, and $\lg A$ immunoreactivities in correlation to strain pathogenicity. Parasitol Res. 2001;87:651-6.

17. Seijo Martinez M, Gonzalez-Mediero G, Santiago P, Rodriguez De Lope A, Diz J, Conde C, Visvesvara GS. Granulomatous amebic encephalitis in a patient with AIDS: isolation of Acanthamoeba sp. group II from brain tissue and successful treatment with sulfadiazine and fluconazole. J Clin Microbiol. 2000;38:3892-5.

18. Singhal T, Bajpai A, Kalra V, Kabra SK, Samantaray JC, Satpathy G, Gupta AK. Successful treatment of Acanthamoeba meningitis with combination oral antimicrobials. Pediatr Infect Dis J. 2001;20:623-7.

19. Lackner P, Beer R, Broessner G, Helbok R, Pfausler B, Brenneis C, Auer H, Walochnik J, Schmutzhard E. Acute granulomatous Acanthamoeba encephalitis in an immunocompetent patient. Neurocrit Care. 2010;12:91-4.

20. CDC. Investigational drug available directly from CDC for the treatment of infections with free-living amebae. MMWR Morb Mortal Wkly Rep 2013, 62:666.

\section{Ready to submit your research? Choose BMC and benefit from:}

- fast, convenient online submission

- thorough peer review by experienced researchers in your field

- rapid publication on acceptance

- support for research data, including large and complex data types

- gold Open Access which fosters wider collaboration and increased citations

- maximum visibility for your research: over $100 \mathrm{M}$ website views per year

At BMC, research is always in progress.

Learn more biomedcentral.com/submissions 